\title{
SOCIO-ECONOMIC AND ADMINISTRATIVE DETERMINANTS OF SMALL-SCALE IRRIGATION SCHEME IN SOUTH-ARI DISTRICT, SNNPR, ETHIOPIA
}

\author{
Dawit Dandano Jarso \\ Jinka University, Department of Agricultural Economics, P.O. Box 165, Jinka, Ethiopia \\ DOI: https://doi.org/10.51193/IJAER.2020.6503
}

\begin{abstract}
Ethiopia is mainly a rain fed agricultural country particularly arid and semi-arid parts of South omo. That's why, government initiated to introduce improved agricultural technologies mainly small-scale irrigation schemes. Despite these efforts, yet, farmers in the study area are found to be unwilling to adopt small-scale irrigation. Thus, this study investigated the socio-economic and institutional determinants of small-scale irrigation schemes, its contribution in the livelihoods and farm income improvement of smallholder farmers in south omo particularly south-Ari districts. The primary data was obtained through a questionnaire interviewed from sample of 150 respondents; 90 from irrigation user and 60 non-user households drawn proportionally from randomly selected four kebeles. Descriptive statistics and Heckman's two-stage estimation were used to estimate determinants of small-scale irrigation participation and household income. The analysis revealed that participation in off-farm activities, supervision, face with crop loss, sex, market problem faced are important determinants for participating in small-scale irrigation schemes. Moreover, participation in irrigation, total livestock unit holding are positively and significantly associated with household total annual income. Finally, based on the results, it is vital to undertake effective measures improving households' participation in small-scale irrigation likewise improve their total annual income.
\end{abstract}

Keywords: Small-scale irrigation, South-Ari, Heckman's two-stage

\section{INTRODUCTION}

Ethiopia is predominantly an agricultural country with the vast potential resources to produce agricultural output. In spite of, its immense natural resource base Ethiopia is a standout amongst the most underdeveloped countries of the world. The agriculture is believed as backbone of the country economy in which majority of its population directly involved and accounts for nearly 
International Journal of Agriculture and Environmental Research

ISSN: 2455-6939

Volume: 06, Issue: 05 "September-October 2020"

$46.4 \%$ of the GDP growing at an annual rate of 7\%, generates more than $85 \%$ of the foreign exchange earnings and employs about $85 \%$ of the labor force( (MoAR, 2012).

Having all these importance, Ethiopian agriculture continued facing a number of problems and challenges namely; adverse climatic conditions, rainfall dependency, lack of appropriate land use system resulting in soil and other natural resources degradation (Belay and Degnet \& Spielman et al. 2004)

Adopting improved sustainable technologies, can help Ethiopian smallholder farmers to mitigate the aforementioned Problems. Some of these technologies may include improved water management in agriculture through the adoption of small-scale irrigation, use of improved crop varieties, fertilizers and other innovative practices more suited to their local conditions (FAO 2013).

As a result, small-scale irrigation is one of these improved agricultural technologies, which have the capability to increase agricultural productivity of arid and semi-arid areas of the country. The areas around south omo zone (lower zone) covering Dasenech, North-Ari, south-Ari, Benatsemay, Hamer, Yanghatom, salamago are semi-arid that receives less, erratic and unreliable rainfall for agricultural production. As stated by Zhou et al., (2009) the main challenge in developing small-scale irrigation has been the insufficient institutional administration and other determining factors at both national and local level.

The agricultural production in Ethiopia is principally rain fed, so it depends on erratic and often insufficient rainfall. As a result, there is a frequent failure of agricultural production. Irrigation technology gained with the potential to stabilize agricultural production and mitigate the negative impacts of variables like deficiency of rainfall (Agerie, 2017). Irrigation promotes agricultural production through increasing crop yields, enabling farmers to increase cropping intensity and switch to high-value crops or commercialize (Asayehegn et al., 2011)

The current government has undertaken various activities to expand irrigation in the country. The country's strategy Agricultural Development Led Industrialization (ADLI) considers irrigation development as a key input for sustainable development. Thus, irrigation development, mainly small-scale irrigation planned to be accelerated (MoFED 2010).

Although Ethiopia has a vast potential in terms of surface and ground water availability and land suitable for irrigation scheme, the adoption of small-scale irrigation is still in its infant stage. The major constraints that inhibit the adoption are predominantly primitive nature of the overall existing production system, shortage of agricultural inputs, limited awareness among the society, limited trained work force and inadequate extension services (MoA 2011a) 
Announcing to the development policy of the country, the Zonal government of South Omo is encouraging irrigation expansion to rise and stabilize food production in the area.

In the South-Ari District, the government is implementing different agricultural development program in order to sustain the food security in rural households. Among these programs, the government primarily takes irrigation development. But such interventions are encountering various social and technical problems (lack of technical person to maintain motor pump, impurity of improved seeds, delay of input supply, unfairness of farmers demand and supply and lack of market access especially for vegetable crops ) that have challenged the strategy and implementation approaches (BoARD, 2006).

Nevertheless, the study area lacks in-depth studies on recognizing the determinants that influence the use of irrigation water. This means the program was not well supported by enough researches which could examine the cropping practice and farm income variation of irrigated and non-irrigated (rain-fed) households in the district. Even if some studies done in different corner of the country on the determinants of irrigation participation, no study was conducted in this study area; yet, little information is available and no works had been done so far on the proposed topic and at the study area. Therefore, this study was tried to fill these gaps by investigating the determinant of rural households' participation in small-scale irrigation and its contribution on rural household income in the study area.

\section{RESEARCH METHODOLOGY}

\subsection{Description of the study Area}

The study was conducted at South Aari district which was one of the nine districts in South Omo Zone. It is the nearest to the capital of the zone, Jinka. Capital of the district, Gazer, is $17 \mathrm{~km}$ away from Jinka. The district has 46 rural kebeles 5 administrative towns, having total area of 513.1319 square kilometers (51313.19 hectares) With land use pattern of 35209.09 ha agriculturally cultivated, 8017 ha was being used for grazing, 2846 ha for forest, and 5241.1 ha residence areas and others arable lands(WOAD, 2018). The area is located in part of the semiarid, kola, weynadega and Dega with various topography high land midland lowlands, which support agro-pastoral groups who are at various stages of transition from nomadic to sedentary livelihoods. It has a total population of 168,225 , which is about $35 \%$ of the zone population. In this district, there was one indigenous ethnic society, which has its own language and unique culture called Aari. 


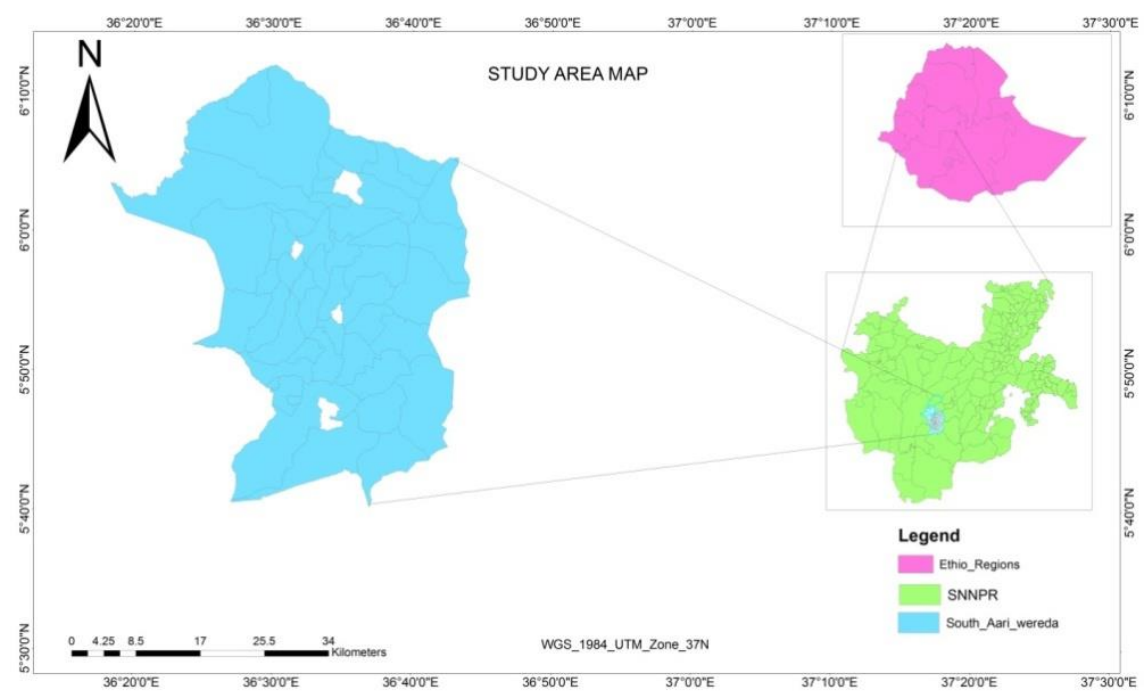

Source: Adopted from South omo map

Figure 2.1: Map of the study Area

\subsection{Research Design, Data Types, Sources, and Methods of Collection}

In this study cross sectional design ${ }^{1}$ was used which is preferred for its high degree of accuracy, relatively less costly, easy to administer questionnaires and interviews for different farmers and also helps to collect all relevant data at single point of time (Janet 2006).

Mark et al. (2009) argued that mixing qualitative and quantitative data gives the potential to cover each method's weaknesses with strengths from the other method. Thus, in this study, the combinations of qualitative and quantitative approaches or type of data were employed.

The study employed both primary and secondary sources of data. The primary information were obtained from irrigation users and non-users through structured and semi-structured questionnaire; whereas, secondary data was obtained from published and unpublished works and different books. The data were collected through semi-structured questionnaires (cross-sectional survey).

\footnotetext{
${ }^{1}$ Cross-sectional study design is a type of observational study design, in which the investigator measures the outcome and the exposures in the study participants at the same time.
} 


\subsection{Sampling Methods and Sample Size}

In this study, three stage sampling techniques were used for sample determination. In the first stage, out of 9 districts under the current administrative structure of South Omo Zone, south-Ari district was selected purposively because of its irrigation potential. In the second stage, out of 46 rural kebeles in south-Ari district, four kebeles were purposively selected on the basis of their irrigation potentials and accessibility. In the third stage, initially the household heads in the four-sample kebeles are identified and stratified in to two strata-irrigation users and non-users. The lists of total households in the selected Kebeles and the lists of irrigation user households in these kebeles were obtained from DOFED and DOID ${ }^{2}$ respectively. The nonusers were selected within kebeles of irrigation users to ensure homogeneity of factors except irrigation. Then the sample respondents from each stratum were selected using simple random sampling technique. The total sample of was 150 rural households, among which 60 households from irrigation non-user and 90 irrigation user households have been drawn proportionally by considering representativeness based on their involvement in irrigation scheme. Since, the population is stratified the sample size of the respondents were determined by using (Kothari 2004)sampling design formula:

$$
n=\frac{Z^{2} p q N}{e^{2}(N-1)+Z^{2} p q}
$$

Due to the homogeneity nature of the population $7 \%$ of error term ( $(\mathrm{e}=0.07)$ was used to take representative and cost effective data for this study.

$$
n=\frac{(1.96)^{2} 0.5 * 0.5 * 54103}{(0.08)^{2}(54103-1)+(1.96)^{2} * 0.5 * 0.5}=150
$$

Table 3.1: Sample determination

\begin{tabular}{lccccccc}
\hline No & $\begin{array}{l}\text { Name of } \\
\text { institutions }\end{array}$ & Total non-user & $\begin{array}{l}\text { Total } \\
\text { users }\end{array}$ & Entire popn & $\begin{array}{l}\text { users } \\
\text { sample }\end{array}$ & $\begin{array}{l}\text { Non-Users' } \\
\text { sample }\end{array}$ & $\begin{array}{l}\text { Sample } \\
\text { size }\end{array}$ \\
\hline \hline 1. & Aykamer & 7,607 & 6,763 & 14,370 & 21 & 18 & 39 \\
2. & Dramer & 8,645 & 4,878 & 13,523 & 24 & 13 & 37 \\
3. & Goydamer & 6,329 & 5,702 & 12,031 & 18 & 16 & 34 \\
4. & Malater & 9,586 & 4,593 & 14,179 & 27 & 13 & 40 \\
\hline & Total & 32,167 & 21,936 & 54,103 & 90 & 60 & 150 \\
\hline
\end{tabular}

Source: Own computation, 2019

\footnotetext{
${ }^{2}$ District Office of Finance and Economic Development and District Office of Irrigation Development 
International Journal of Agriculture and Environmental Research

ISSN: 2455-6939

Volume: 06, Issue: 05 "September-October 2020"

\subsection{Method of Data Analysis}

The study employed descriptive statistics (mean, percentage and frequency) to distinguish the irrigation participants from the group of non-participants. Since the two groups considered independent, test of hypotheses was carried out by using student's t-test for quantitative variables (continuous) and Chi-square test for qualitative variables (discrete).

In addition, the study also used econometric models involving regressions applicable with dummy dependent variable model. The dependent variable in this study is a dummy variable, which takes a value of zero or one depending on whether or not the households participate in small-scale irrigation. However, the independent variables are of both types that are continuous or categorical (Maddala 1983).

In view of the need to estimate the selection process in to the irrigation program, the Heckman two stage selection models were employed. This approach is chosen because it considers for selection bias that could arises due to unobservable factor. The common version of the Heckman procedure is to estimate in two stages. In the first stage, estimate the selection or participation equation (the probability of participating in small scale irrigation) using probit model and derives maximum likelihood estimates with data from both participants and nonparticipants, using the estimation result "Inverse Mills ratio" is constructed. The inverse Mills ratio (lambda) is the tool for controlling bias due to sample selection (Heckman 1979). The second stage involves including the Inverse Mills ratio as an additional explanatory variable to the household income equation or outcome equation and estimating the equation using OLS model using data from the participant households only. If the coefficient of the 'selectivity' term is significant then the hypothesis that the participation equation is governed by an unobserved selection process or selectivity bias is confirmed. Moreover, with the inclusion of extra term, the coefficient in the second stage 'selectivity corrected' equation is unbiased (Zaman 2001). Therefore, we are interested to apply Heckman's two-stage model for this study since it simultaneous model i.e. the decision to participation in small-scale irrigation and the effect of small-scale irrigation schemes on the income of households.

\subsection{Model specification}

In order to achieve objective one and two the following functional forms were used.

$P_{i}=f\left(Z_{1}, Z_{2}, Z_{3}, Z_{4}, Z_{K}\right)$

The econometric model for the probit model stated in equation (2) can be specified as:

$\mathrm{P}_{\mathrm{i}}=\alpha+\alpha_{1} Z_{1}+\alpha_{2} Z_{2}+\cdots \alpha_{k} Z_{k}+\mu$ 
Volume: 06, Issue: 05 "September-October 2020"

Where, $\mathrm{P}_{\mathrm{i}}=$ dichotomous dependent variable representing participation of smallholder farm households in small-scale irrigation; $Z k$ vector of variables that affect smallholder farm households' decision to participate in small scale irrigation $\alpha \mathrm{k}$, Parameters coefficients to be estimated, and $\boldsymbol{\mu}$ is the error term.

$\mathrm{Yi}=\mathrm{f}\left(\mathrm{X}_{1}, \mathrm{X}_{2}, \mathrm{X}_{3}, \mathrm{X}_{4} \ldots \mathrm{X}_{\mathrm{k}}\right)$

The econometric model for the outcome model stated in equation (4) can be specified as:

$Y=\beta_{0}+\beta_{1} X_{1}+\beta_{2} X_{2}+\cdots \cdot \beta_{K} X_{K}+\lambda+\varepsilon_{i}$

Where, $Y=$ represents the amount of income from small-scale irrigation activities. $X_{1}, X_{2}, X_{3}, X_{4}$, $\mathrm{X}_{\mathrm{K}}$ are determinants of smallholder farm households small scale irrigation income $\beta$ parameters; represent coefficients for the row vectors to be estimated, $\lambda$ is the inverse mills ratio and $\boldsymbol{\varepsilon}_{\boldsymbol{i}}$ is the error term with standard properties.

Table 3.2: Definition of predicted variables and hypothesis

\begin{tabular}{|l|l|l|l|l|c|}
\hline No & Name of Variables & Symbol & Variable Type & Measurements & Sign \\
\hline 1. & Participation in irrigation scheme & partirrig & dummy & lif participated, 0 otherwise & \pm \\
\hline 2. & Access to credit service & accredit & dummy & $\begin{array}{l}1 \text { if there is access, } 0 \\
\text { otherwise }\end{array}$ & + \\
\hline 3. & Access to extension service & accexten & dummy & $\begin{array}{l}1 \text { if there is access, } 0 \\
\text { otherwise }\end{array}$ & + \\
\hline 4. & Access to market information & accinfo & dummy & 1 if has access, 0 otherwise & + \\
\hline 5. & Age of household head & agehh & continuous & years & - \\
\hline 8. & Distance from the water source & diswtrs & continuous & Km & - \\
\hline 9. & Education level of household head & educl & Continues & Years of schooling & - \\
\hline 10. & Family labor force available & famlabor & continuous & number & + \\
\hline 11. & Sex of household head & sexhhead & dummy & 1 if male, 0 otherwise & \pm \\
\hline 12. & cultivated farm land Size & cultland & continuous & hectare & + \\
\hline 13. & Soil fertility status & soilferts & dummy & 1 if fertile, 0 otherwise & + \\
\hline 14. & Annual farm income & anfinc & continuous & birr & + \\
\hline
\end{tabular}


International Journal of Agriculture and Environmental Research

ISSN: 2455-6939

Volume: 06, Issue: 05 "September-October 2020"

\begin{tabular}{|l|l|l|l|l|l|}
\hline 15. & Total livestock owned & livstown & continuous & TLU & - \\
\hline
\end{tabular}

Source: Own construction, 2019

\section{RESULT AND DISCUSSION}

\subsection{Descriptive Statistics for Discreet Socio-Economic and Administrative Factors}

\subsubsection{Gender}

The findings in table 3.1 show that out of 150 respondents, $63 \%$ were male and $37 \%$ were female. While women could identify socio-economic impact such employment creation and availability of adequate income; men identified socio-economic impact such as adequate production leading to increased crop yields and increased crop areas as accrued from irrigation scheme. The portion of non-users was $13(8.67 \%)$ for males, whereas, $47(31.3 \%)$ for female counter parts. This reveals that from their respective sex composition, male were more engaged in irrigation than female respondent in line with report by Agerie (2017). However, the chi-square result shows that the association between sex and irrigation usage is significant $(\chi 2=71.8513 \mathrm{P}=0.000)$ (Table 3.1). This observation probably due to variety of cultural and structural limitations restrict women's participation in water management and although women were involved in agricultural activities, their contributions were mainly considered to be supporting roles and undervalued compared to men.

\subsubsection{Supervision and training}

About $80 \%$ ( $54 \%$ users and $26 \%$ non-users) are those who informed that they have been supervised by institute bodies like DAs. The chi $2=14.06$ indicates that there was a significant difference between user and non-users, at $1 \%$ significance level. The implication is that the continuous follow up of farmers provides them to pay attention to their irrigated produces and able to increase their perception of responsibility toward water management.

Training provision by DAs increases the prospect of participating in irrigation scheme and improves the livelihood of the farm household. This might be because of the training helps them to use the water efficiently in wet as well as in dry seasons. The training also enables them to react more easily for the difficult they face through informal ways. Moreover, training on irrigation water management contribute to pause rural households' socio-economic poverty and preserve gender mainstreaming in each irrigation management activities.

\subsubsection{Reason for not using irrigation}


International Journal of Agriculture and Environmental Research

ISSN: $2455-6939$

Volume: 06, Issue: 05 "September-October 2020"

Regarding the cause of being nonattendance in irrigation scheme, 89(59\%) from which 14\% users and $44.67 \%$ non-users replied that the reason hindering them not to participate in irrigation was the lack of water nearby farm land. Besides, 56(37\%) from which $25 \%$ users and $12 \%$ nonusers reacted that lack the sufficient information about the improved small scale irrigation program. Thus, the aforementioned causes are main reason for households not participating in the scheme.

\subsubsection{Soil quality}

The survey result presented that in the study area soil fertility is not a serious problem. Majority of the respondents said that the soil fertility status is moderate such that $70 \%$ of the sample respondents replayed that their farm land is moderately fertile, and only $14 \%$ percent of them reported that their land is not fertile. The comparison between user and non-user households showed that $31.33 \%$ of the users and $39.33 \%$ of the non- users have fertile land in their view. The chi square test revealed that there is a statistically significant relationship between soil fertility status and access to irrigation at $1 \%$ level of significance.

\subsubsection{Access to Credit}

In the study area, about $23 \%$ of non-user households and $77 \%$ user household have access to credit service (Table 3.1.). The chi-square test shows that there was significant difference between non-user $\mathrm{HH}$ and user $\mathrm{HH}$ in credit access (Chi2 $(1)=17.1400 \mathrm{Pr}=0.000$ ) which similar to Kalkidan (2016). Mostly, those irrigation users get credit access from informal financial institutions (friends, neighbors). Since irrigation practice is seasonal, seasonal changes such as drought, pest and insect damage negatively influence the amount of output expected. Thus, to achieve higher productivity, well-timed access to short-term finance for inputs was essential.

Credit access can be used to enhance farm productivity and to ensure sustainable food production. Irrigation users who have access to credit can overcome their financial constraints and can purchase all necessary inputs for their farm production. However, farmers without cash and have no access to credit service thus it is difficult to them to produce capital intensive crops. That is also what is explained by Adeniyi (2010) which indicated those female headed households have less credit access and thus they are not getting high yield per hectare in Ethiopia. 
International Journal of Agriculture and Environmental Research

ISSN: 2455-6939

Volume: 06, Issue: 05 "September-October 2020"

Table 4.1: Summary of descriptive statistics for discrete variables by participation in irrigation

\begin{tabular}{|c|c|c|c|c|c|c|c|c|}
\hline \multirow[t]{2}{*}{ Variable description } & & \multicolumn{2}{|c|}{ Users } & \multicolumn{2}{|c|}{ Non-users } & \multicolumn{2}{|c|}{ Total } & \multirow[t]{2}{*}{$\chi^{2-\text { value }}$} \\
\hline & & $\mathrm{N}$ & $\%$ & $\mathrm{~N}$ & $\%$ & $\mathrm{~N}$ & $\%$ & \\
\hline \multirow{3}{*}{$\begin{array}{l}\text { Sex of household } \\
\text { head }\end{array}$} & Female & $\overline{9}$ & 6.00 & 47 & 31.33 & 56 & 37.33 & 71.85 \\
\hline & Male & 81 & 54.00 & 13 & 8.67 & 94 & 62.67 & $\operatorname{Pr}=0.000$ \\
\hline & Total & 90 & 60.00 & 60 & 40.00 & 150 & 100.00 & \\
\hline \multirow{3}{*}{$\begin{array}{l}\text { Have you ever been } \\
\text { Supervised \& } \\
\text { trained by Das? }\end{array}$} & No & 9 & 6.00 & 21 & 14.00 & 30 & 20.00 & 14.06 \\
\hline & Yes & 81 & 54.00 & 39 & 26.00 & 120 & 80.00 & \\
\hline & Total & 90 & 60.00 & 60 & 40.00 & 150 & 100.00 & $\operatorname{Pr}=0.000$ \\
\hline \multirow[t]{4}{*}{$\begin{array}{l}\text { Reason for not using } \\
\text { irrigation? }\end{array}$} & $\begin{array}{l}\text { No farm land } \\
\text { nearby water }\end{array}$ & 22 & 14.67 & 67 & 44.67 & 89 & 59.33 & 30.0997 \\
\hline & $\begin{array}{l}\text { Lack of } \\
\text { information about } \\
\text { irrigation }\end{array}$ & 38 & 25.33 & 18 & 12.00 & 56 & 37.33 & $\operatorname{Pr}=0.000$ \\
\hline & $\begin{array}{l}\text { lack of advanced } \\
\text { tool }\end{array}$ & 0 & 0.00 & 5 & 3.33 & 5 & 3.33 & \\
\hline & Total & 60 & 40.00 & 90 & 60.00 & 150 & 100 & \\
\hline \multirow[t]{5}{*}{ Soil quality } & Very fertile & 1 & 0.67 & 20 & 13.33 & 21 & 14 & 14.3029 \\
\hline & Fertile & 47 & 31.33 & 59 & 39.33 & 106 & 70.67 & $\operatorname{Pr}=0.003$ \\
\hline & Poor/infertile & 12 & 8.00 & 10 & 6.67 & 22 & 14.67 & \\
\hline & Undefined & 0 & 0.00 & 1 & 0.67 & 1 & 0.67 & \\
\hline & Total & 60 & 40.00 & 90 & 60.00 & 150 & 100 & \\
\hline \multirow{3}{*}{$\begin{array}{l}\text { Do you have access } \\
\text { to credit? }\end{array}$} & No & 10 & 6.67 & 24 & 16.00 & 34 & 22.67 & 17.14 \\
\hline & Yes & 80 & 53.33 & 36 & 24.00 & 116 & 77.33 & $\operatorname{Pr}=0.000$ \\
\hline & Total & 90 & $60 \%$ & 60 & $40 \%$ & 150 & 100 & \\
\hline
\end{tabular}

Source: Survey data computation 2019

\subsection{Descriptive Statistics for Continuous Variables}

\subsubsection{Age of the farm household}

According to the result of table 3.2 the average age distribution of the total sample respondents was 36.73 years with standard deviation of 8.56. From which the average age of the user household was 34.82 year with a standard deviation of 8.56 and for the non-user household was found 38.00 years with the standard deviation of 8.37. Accordingly, the t-test result revealed that the average age difference between the two groups is found to be statistically significant and it shows the higher the age of household the lower the participation in irrigation scheme. And this might be due to reason that the operation of irrigation equipment like pump needs force which could not be realized by aged people. 


\subsubsection{Distance from Water Source}

Based on the results in table 3.2 the average distance of the sample household head's farmland from source of water takes $2.28 \mathrm{hr}$ with the standard deviation of 0.08 . The average distance for user household head was found $2.11 \mathrm{hr}$ with standard deviation of 0.1 . And for the non-user group was found $2.54 \mathrm{hr}$ with the standard deviation of 0.13 . The t-test result for those two groups indicated that there was significant difference in the distance from water source at $1 \%$ significance level. Therefore, the respondents' household farm located far from the rivers and main irrigation canals has less chance to use irrigation water and vice versa similar to the result of (Agidew 2012).

\subsubsection{Annual On-Farm Income}

The results in Table 3.2 show that the mean annual on-farm income obtained by the irrigation user and non-user respondents' household was 2065.17 and 1494.00 respectively. The t-value analysis (Table 3.2.) result revealed that farm income affects participation in irrigation positively at $5 \%$ significance level. The possible explanation is that those household who had sufficient gain from farm income: sale of crop, livestock, and their products are more likely to be irrigation participants than those who did not gained enough from farm income. This result supports the study by (Tsegaye and Bekele, 2010; Asayehegn et al., 2012 n.d.).

Table 4.2: Summary statistics and distribution of continues variables

\begin{tabular}{|c|c|c|c|c|c|c|c|c|}
\hline \multirow[t]{2}{*}{ Variable } & \multicolumn{2}{|l|}{ User } & \multicolumn{2}{|c|}{ Non-User } & \multicolumn{2}{|l|}{ Total } & \multirow[t]{2}{*}{ t-value } & \multirow[t]{2}{*}{ p-value } \\
\hline & Mean & Std. Dev. & Mean & $\begin{array}{l}\text { Std. } \\
\text { Dev. }\end{array}$ & Mean & Std. Dev. & & \\
\hline AGFRM & 34.82 & 8.56 & 38.00 & 8.37 & 36.73 & 8.56 & 2.26 & $0.02 * *$ \\
\hline EDUL & 1.55 & .18 & 1.76 & .19 & 1.68 & 1.64 & 0.79 & 0.43 \\
\hline DSFWRS & 2.115 & .10 & 2.54 & .13 & 2.28 & .08 & -2.59 & $0.01 * *$ \\
\hline ANONFI & 2065.17 & 1474.81 & 1494.00 & 1243.93 & 1722.47 & 1365.41 & 2.56 & $0.01 * *$ \\
\hline LNDSZ & 1.67 & 1.18 & 1.62 & 1.02 & 1.64 & 1.08 & -0.24 & 0.8 \\
\hline FMlLSZ & 6.53 & 2.42 & 6.32 & 2.38 & 6.406 & 2.39 & -0.53 & 0.59 \\
\hline FEXCNT & 2.21 & 1.83 & 2.45 & 1.60 & 2.36 & 1.69 & 0.84 & 0.39 \\
\hline EXPIRRU & 3.28 & 1.78 & 3.12 & 1.44 & 3.18 & 1.58 & -0.61 & 0.54 \\
\hline
\end{tabular}

Note: ** Indicates significance at the $5 \%$ level

Source: Survey data computation 2019 
International Journal of Agriculture and Environmental Research

ISSN: 2455-6939

Volume: 06, Issue: 05 "September-October 2020"

\subsection{Irrigation Participation and Its Effects on Income}

As already stated in the methodology part, this study employs the Heckman two-stage model to estimate and infer the parameters of the determinants of small-scale irrigation participation decision by smallholder farmers and its effect on income of the farm household in the study area. The first stage of the Heckman sample selection model was the probit model which assessed the determinants of irrigation participation. The second stage holds the outcome model (OLS) which examined the effect of irrigation participation on income of the farm household.

\subsubsection{Determinants of irrigation participation}

Supervision by Development Agents: Consistent with a priori expectation this variable was significant at $10 \%$ significance level and positively related to household participation decision on small-scale irrigation. The marginal effect result from (Table 3.3) reveals that for discrete change in dummy variable from non-supervised to supervised, the probability a farmer to be irrigation user increase by 30.17 percent. This implies that all other things being kept constant, the more training and technical advice is provided by the extension agent to the farmers, the higher is the probability of the farmers to use small scale irrigation.

Sex of the household: Analogous to the expected sign the results of the logit model revealed that sex of the farm household associated positively and significant at less than 5\% probability level. The possible explanation is that, male headed households are more likely to adopt modern irrigation system than female headed household. This is because females in the study area are with well-known triple burden (production, reproductive and childcare), and also they have less access to information about the technology due to the above mentioned burden than male headed household, then due to the case of sex difference of household head has influenced the smallscale irrigation participation. Moreover, with regard to farming experience males are better than the female farmers since it is assumed that male household heads have more exposure and access to information and new interventions than female household heads, which might enable them to participate in the small scale irrigation as early as possible than their counterpart. Thus, from the survey result marginal effect revealed that keeping all other factors constant at their mean value, for the discrete change from 0 to 1 in gender of the household head increases the probability of participation in small-scale irrigation by 30.72 percent points more chance of participation in small-scale irrigation than female headed households. On the other hand, the main reasons for absence of women participation in irrigation are:-Unable to work at night; a lot of domestic work at home; other perceptions; such as men know more how and what to say in meetings and in public congregations and males also have more ability to convince others in conflict resolution cases. The result is parallel with report by (Agerie, 2017) 
International Journal of Agriculture and Environmental Research

ISSN: 2455-6939

Volume: 06, Issue: 05 "September-October 2020"

Participation in Off-farm Activities: It is also obvious from the result, as antagonistic to the prior anticipation, the households engaged in one or more off-farm activities such as handicraft, petty trade, local brewing, working as daily laborer on the farm of others, and the like are likely unable to participate in irrigation as shown by the negative and statistically significant coefficient effect at $1 \%$ significance level. For a discrete change of the dummy variable on behalf of participant from 0 to 1 , the probability a farmer to be irrigation user decrease by 43.39 percent. This might be due to the fact workload and indeed off-farm activities were additional sources of income for smallholder farmers and the cash generated from these activities could back up the farmers' income to settle their economic problems other than on farm activities.

Crop loss problem: This is another agro-economic factor that was found to influence the farmers' participation in small-scale irrigation negatively as hypothesized earlier and significant at $1 \%$ significance level. The possible explanation as that the incidence of crop loss due to natural and human factors for instance: erratic, unreliable or insufficient rainwater supplies, disease, post-harvest loss of perishable horticultural crops(like vegetables), pests, climate variability and change, water lockage, decreases the likelihood of a farmer in small-scale irrigation by 74.13 percent.

Marketing problems: Resembling to our expectations marketing problem was found influencing farmers irrigation participation negatively at $1 \%$ significance level. The market problem such as frequent low price at peak supply periods, lack of marketing chain, information gap and distance from local market are the major market problems in the study area though more farm household appear to face such problems. Likewise, market problem might be due to different factors affecting the timely delivery of irrigation products to markets and quality of product (e.g. as a result of non-existence of storage, lack of transportation facilities, bulkiness and perishable nature of the product), majority of irrigation users produced almost the same types of vegetables which leads to bulk inventories. In the same way, the current study show for a discrete change of the dummy variable from 0 to 1 on behalf of smallholder farmer face market problems, the probability of a farmer participate in small-scale irrigation decrease by 43.25 percent.

\subsubsection{Effect of Irrigation Participation on Farmers Livelihood}

The result of the estimated ordinary least squares (OLS) part or the second step of the Heckman model is presented in Table 3.3. Among many variables of the finding, the result revealed that participation in small-scale irrigation and total livestock holding of the farm household were the only variables that that have positively significant influence on the rural farmers' annual on-farm income as a result of participation in irrigation scheme. 
Participation in Irrigation: Results showed that participation in irrigation has a significant, positive effect on farm households' income at $1 \%$ significance level. For discreet change for farm household participation in irrigation from 0 to 1 increase the income of the household by 174.4 factors (Betre and Mahelet 2007). Here it is to mean that irrigation does not only raises the yields of specific crops, but also prolongs the effective crop growing period in area with dry seasons, thus permitting multiple cropping (two or three and sometimes four crops per year) where only a single crop could be grown. It is acknowledged as an important element in the economic improvement process, it must contribute to increased agricultural output and productivity, and the resulting benefits must be equitably distributed among women and men and between social classes. In similar was Kalkidan F. (2016) stated that participation in irrigation management practices is very crucial to improve the productivity of small scale irrigation agriculture.

Total livestock holding: Consistent with a priori expectation livestock holding, measured in tropical livestock unit, was found to have positive and significant effect at $1 \%$ level of significance on the probability to participation in small-scale irrigation which confirms the hypothesis. The positive relationship indicates that households with larger livestock holding may have money to spend on any possible cost to participate in the irrigation activity. Moreover the implication of the result was that livestock are an important source of cash in rural areas to allow purchase of farm inputs that are needed to participate in small-scale irrigation. Farmers who have large number of livestock might consider their asset base as a mechanism of insuring any risk associated with the participation in small-scale irrigation. In addition to the provision of the purchase power, the livestock serve as a source of additional income and food. Livestock may also serve as a proxy for oxen ownership, which is important for farm operations. Here the result of OLS estimates shows that as the number of livestock in tropical livestock unit increase by one unit, the income of one who participate in small-scale irrigation increases by 79.75 factors, despite the fact keeping all covariates constant at their mean value, similar to the results reported by Agerie (2017).

Table 3.3: Heckman two stage estimates and marginal effect after probit model

\begin{tabular}{lccccc}
\hline PARTIRRGAN & Coef. & Std. Err. & $\mathbf{z}$ & P>z & Marginal effect \\
\hline \hline DAsup $^{\wedge}$ & .788 & .468 & 1.68 & 0.092 & $.302 *$ \\
FCPL^ $^{\wedge}$ & -2.259 & .510 & -343 & 0.000 & $-.741 * * *$ \\
DPSWIRR $^{\wedge}$ & .1230 & .507 & 0.24 & 0.808 & .044 \\
POFFA $^{\wedge}$ & -1.184 & .406 & -2.92 & 0.004 & $-.434 * * *$ \\
PRBFMKT $^{\wedge}$ & -1.185 & .384 & -3.09 & 0.002 & $-.433 * * *$ \\
SXHHH^ $^{\wedge}$ & .825 & .369 & 2.23 & 0.025 & $.307 * *$ \\
UAGRT $^{\wedge}$ & .536 & .567 & 0.95 & 0.345 & .180 \\
\multicolumn{1}{c}{ cons } & 2.432 & .846 & 2.87 & 0.004 & - \\
\hline
\end{tabular}


International Journal of Agriculture and Environmental Research

ISSN: $2455-6939$

Volume: 06, Issue: 05 "September-October 2020"

\begin{tabular}{|c|c|c|c|c|c|c|}
\hline \multicolumn{5}{|l|}{ ANONFI } & \multicolumn{2}{|c|}{ [95\% Conf. Interval } \\
\hline ACCINFO & -257.196 & 243.604 & -1.06 & 0.291 & -734.65 & 220.250 \\
\hline EDUl & 21.428 & 67.549 & 0.32 & 0.751 & -110.9662 & 153.822 \\
\hline FEXCNT & 33.701 & 61.677 & 0.55 & 0.585 & -87.18415 & 154.586 \\
\hline FMlLSZ & -18.197 & 52.028 & -0.35 & 0.727 & -120.1717 & 83.778 \\
\hline LNDOW & 125.500 & 142.433 & 0.88 & 0.378 & -153.6646 & 404.665 \\
\hline LNDSZ & 174.473 & 110.472 & 1.58 & 0.114 & -42.04746 & 390.994 \\
\hline PARTIRRGAN & 726.748 & 291.104 & 2.50 & 0.013 & 156.1951 & 1297.301 \\
\hline SOLQL & -296.328 & 206.547 & -1.43 & 0.151 & -701.1539 & 108.497 \\
\hline TTLU & 79.757 & 27.079 & 2.95 & 0.003 & 26.6818 & 132.833 \\
\hline _cons & 1165.955 & 716.393 & 1.63 & 0.104 & -238.1501 & 2570.059 \\
\hline \multicolumn{7}{|l|}{ hazard } \\
\hline lambda & 102.759 & 276.9789 & 0.37 & 0.711 & -440.1095 & 645.628 \\
\hline rho & 0.082 & & & & & \\
\hline sigma & 1250.925 & & & & & \\
\hline \multirow{2}{*}{\multicolumn{3}{|c|}{ Linear regression with endogenous treatment }} & & Number of & \multicolumn{2}{|l|}{$=150$} \\
\hline & & & & Wald chi2( & \multicolumn{2}{|l|}{$=21.53$} \\
\hline \multicolumn{3}{|c|}{ Heckman selection model -- two-step estimates } & & Prob $>$ chi2 & \multicolumn{2}{|l|}{$=0.0105$} \\
\hline
\end{tabular}

Source: Estimation analyzed based survey data 2019

\section{CONCLUSIONS AND RECOMMENDATION}

\subsection{Conclusions}

This study assessed Socio-Economic and Administrative Determinants of Small-Scale Irrigation Scheme in South-Ari District, SNNPR Ethiopia. Based on the information collected from 150 sample respondents of four kebles in studying determinants of smallholder farmers' participation in small-scale irrigation and its effect on income, and the role of women in irrigation management activities one can draw the following conclusions. The descriptive statistics: Chisquare and t-tests were applied for discrete and continuous variables respectively to statistically compare the mean of the two groups (irrigation users and irrigation non-users) with respect to important demographic, socioeconomic and institutional variables. The result shows that $60 \%$ of the total sample respondents were found to be users of small-scale irrigation.

Descriptive statistics result presented in this study revealed that sex of the farm household, supervision \& training, soil quality, access to credit, age of the farm household, distance from water source, annual on-farm income, income from off-farm activities, total livestock unit, 
frequency of extension contact per month were found to the most contributing factors that showed significant difference among irrigation participants and non-participants.

Similar to conventional phenomena, female headed irrigation users in the study area are commonly involved in farm management activities such as removing weeds, and harvesting while male headed participate in heavy and risky tasks such as land clearing, cultivating and planting, crop watering using pump and transporting and loading products. Regarding

The econometric results in the first stage of the Heckman two stage displayed, variables that turned out to be statistically significant include: Supervision by DAs helps farmers to get trainings and technical advices to use small scale irrigation; Male-headed households have higher chance of participation in small-scale irrigation compared to female headed households which is by reason of triple role of women; off-farm activities were indeed additional sources of income that could back up the farmers' income to settle their economic problems other than from irrigation farm: On the other hand, crop loss and marketing problem are also the most hindering factors that discourage farm households not to participate in small scale irrigation.

Moreover, the results of the second stage of the Heckman two-stage estimation revealed that, livestock holding and decision of the farmer to participate in small scale irrigation are found to be positively associated with the level of total annual on-farm income among the participant households.

\subsection{Recommendations}

Based on the findings from the analysis part, in both descriptive and econometric analysis, the following policy recommendation notes can be drawn for further consideration and improvement of irrigation development and income in the study area:

Although women are more numerous in the agricultural sector than the other sectors, have least benefited from the fruit of development. Due to social-cultural reasons Ethiopia women in agriculture are in disparity with men. Hence, measures for women advancement should be an ultimate focus.

$\varangle$ From the thought that Irrigation requires heavy physical strength, in Ethiopia it is reflected as men's job and therefore women are assumed to be unfit. Policy makers especially in the water management agencies should develop policies based on sound concept of gender issues and encourage women to be more active.

T The society should be given an awareness creating trainings in order to promote women in every step of the irrigation systems, starting from planning via implementation of the program up to the management footstep. 
International Journal of Agriculture and Environmental Research

ISSN: 2455-6939

Volume: 06, Issue: 05 "September-October 2020"

$\$$ Along with the empirical result, more attention should be given to the livestock sector at least in the areas: feed improvement and management; genetic improvement; control/prevention of animal diseases and parasites; and development of marketing chain facilities for animal and animal products. However, this needs combined efforts and integrated task of the government, cooperatives, NGOs and the farmers themselves.

$\rightarrow$ According to the result of this study, Farmers' irrigation participation has significant impact on income and livelihood of the society. Thus, it shall be great and rewarding if policy makers, designers implementers, and any funding agencies with like interest further improve the project to achieve the development goals.

$\rightarrow$ The WOAD should employ adequate number of DAs and assist them to make robust contact and flow of information with farm households to increase their participation in small scale irrigation.

To overcome market related problems like includes problem such as sudden change in the demand for irrigation product, difficulties in volatile market price; it is important facilitate the establishment of cooperative organizations that enable accessing larger markets

$\rightarrow$ According to the result of descriptive statistics, agricultural credit should delivered either in cash or in-kind form by government or NGOs, to support poor farmers specially female headed households to for input purchase and ultimately to adopt advanced agricultural technologies like small scale irrigation.

\section{REFERENCES}

1. Agerie N., 2017. . Determinants of Smallholder Rural Farm Households' Participation in Small Scale Irrigation and Its Effect on Income in North Gondar Zone: A Cross-Sectional Approach (Evidence from Dembia District): MSc. thesis MSc. in Economics, Mekele university

2. Belay, K. and Degnet, A. 2004. Challenges Facing Agricultural Extension Agents: A Case Study from Southwestern Ethiopia. African Development Bank, Blackwell Publishing Ltd, Oxford, UK

3. Betre, A., 2006. Geography of Small-Holders' Commercialization: the Case of food grains in Ethiopia. Paper submitted for Ethiopia Strategy Support Program (ESSP) Policy Conference, IFPRI and EDRI, 6-8 June 2006, Addis Ababa, Ethiopia. Available on: http://www.ifpri.org/events/conferences/2006/essp06/alemu.pdf.

4. BoARD, 2006. Strategic plan for 2007-2010.Unpublished Document. Mekelle.

5. FAO. 2013. Climate-Smart Agriculture: Sourcebook; Food and Agriculture Organization of the United Nations: Rome, Italy, 
International Journal of Agriculture and Environmental Research

ISSN: 2455-6939

Volume: 06, Issue: 05 "September-October 2020"

6. Gujarati, S.N. Domoda. 2003. Basic Econometrics. $4^{\text {th }}$ Edition. McGraw Hill Company New York. 595p.

7. Heckman, J. 1976. Sample selection bias as a specification error. Econometric 47: 153161.

8. Janet, M. R. (2006). A Guide to Social Science Research; Essentials of Research Methods; USA,

9. Kalkidan F., 2016. The Role of Gender in Small Scale Irrigation Agriculture among Smallholder Farmers in Lume District in the Central Rift Valley of Ethiopia: M.Sc. Thesis. Wondo-Genet College of Forestry and Natural Resource, Hawassa University, Ethiopia

10. Maddala, G.S. 1983. Limited Dependent and Qualitative Variables in Econometrics. Cambridge University Press, New York.

11. Mahelet, G.F., 2007. Factors Affecting Commercialization of Smallholder Farmers in Ethiopia: The case of North Omo Zone, SNNP region. Paper presented at the Fifth International Conference on the Ethiopian Economy, Addis Ababa, June7-9, 2007.

12. Mark, S. Philip, L. \& Adrian, T., 2009. Research Methods for Business Students. Fifth edition, FT Prentice Hall

13. MoFED. 2010. Ministry of Finance and Economic Development, Performance Evaluation of the First Five Years Development Plan (2006-2010) and Growth and Transformation Planning the next Five Years (2011-2015). A draft document for discussion with the regional/city administration. Addis Ababa, Ethiopia.

14. Spielman D., Byerlee D., Avid J., Alemu D., Kelemework D., 2010. Policies to promote cereal intensification in Ethiopia: The search for appropriate public and private roles, Food Policy, 35: 185-194.

15. Tsegaye, G. and Bekele, W. 2010. Farmers' perceptions of land degradation and determinants of food security at Bilate Watershed, Southern Ethiopia. Ethiopian J. Appl. Sci. Tech. 1(1): 49-62.

16. Virtanen, P., Palmujoki, E. and Dereje Tesfaye. 2011. Global Climate Policies, Local Institutions and Food Security in a Pastoral Society in Ethiopia. The Journal of Sustainable Development Vol. 5, Pp. 96-118.

17. Willy G. C., 2013. Contribution of Small Scale Irrigation Schemes to the Livelihood of Rural Households: The Case of Lumuma Irrigation Scheme in Kilosa District; Morogoro Region, in partial fulfilment of the requirements for award of the MSc degree in Economics of Mzumbe University

18. Woldeab, T. 2003. Irrigation practices, state intervention and farmers life-worlds in drought-prone Tigray. Dissertation, Wageningen University, Netherlands. 
International Journal of Agriculture and Environmental Research

ISSN: 2455-6939

Volume: 06, Issue: 05 "September-October 2020"

19. World Bank, 2006. Ethiopia: Managing Water Resources to Maximize Sustainable Growth. A World Bank Water Resources Assistance Strategy for Ethiopia. Washington DC: World Bank.

20. Zhou, S. D., 2009. Factors affecting Chinese farmers' decisions to adopt a water-saving technology. Canadian Journal of Agricultural Economics 56 (1): 51-61. 